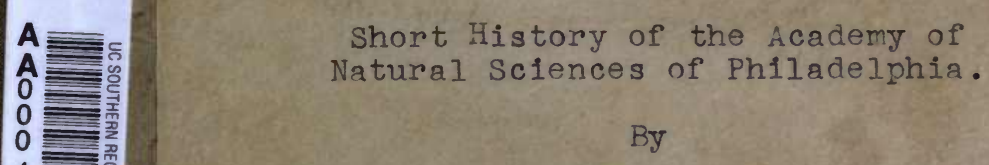

Fdward James Nolan 
UNIVERSITY OF CALIFORNIA AT LOS ANGELES

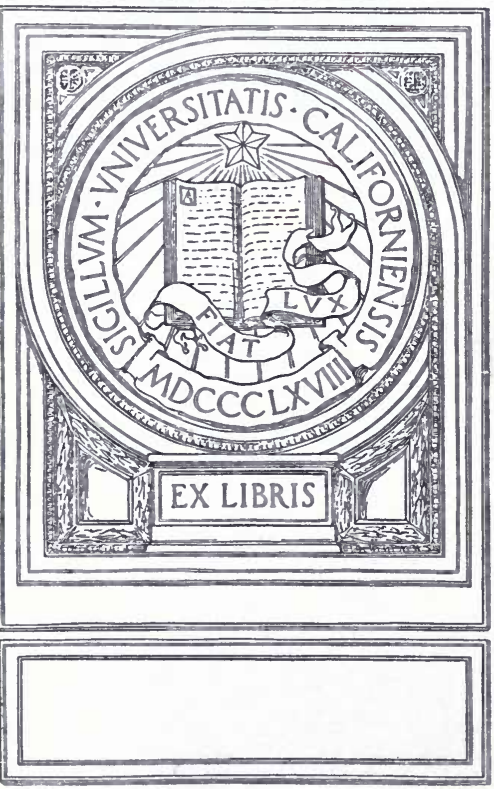




\title{
A
}

\section{SHORT HISTORY}

\author{
OP THE
}

\section{Academy of Natural Sciences}

\author{
OF \\ PHILADELPHIA
}

\author{
BY \\ EDWARD J. NOLAN, M.D. \\ Recording Secretary and Livrarian
}

PHILADELPHLA

The Academy of Natural Sctences

DECEMBER, 1909 


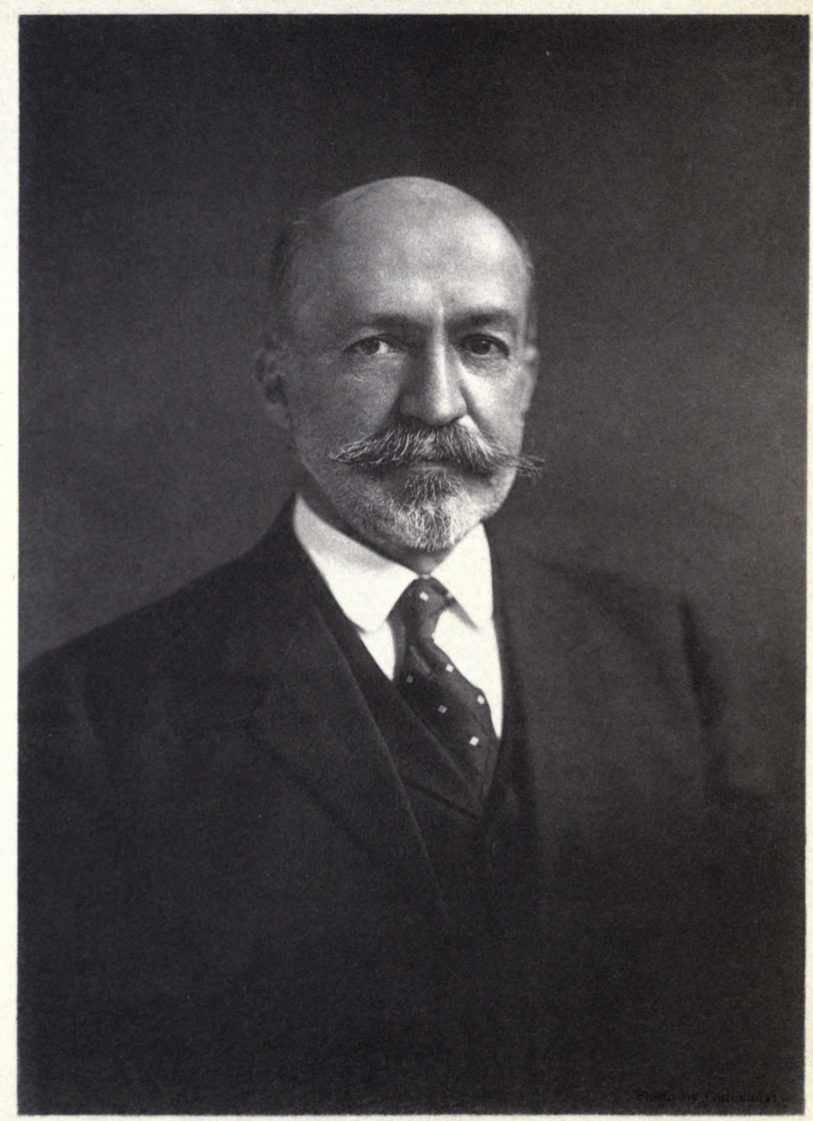

Aammention 


\title{
A \\ SHORT HISTORY
}

OF THE

\section{Academy of Natural Sciences \\ OF}

\author{
PHILADELPHIA
}

BY

EDWARD J. NOLAN, M. D.

Recording Secretary and Librarian

PHILADELPHLA

The Academy of Natural Sciences

DECEMBER, 1909 



\section{QHI
A $16 N 7$}

HIS brief history of the Academy of Natural Sciences
of Philadelphia was prepared as a contribution to the volume issued in commemoration of Founders' Week, so successfully celebrated from the fourth to the tenth of October, 1908.

The length of the article was determined by the number of pages available in the distribution of the matter composing the book and the story is, therefore, necessarily "short." The Notices of Morton and Ruschenberger have been of assistance in preparing the earlier portion.

The sketch may be regarded as merely preliminary to a detailed history of the Academy to be issued in connection with the proposed celebration of the Centenary of the society in 1912. It is sent out in this form with the hope that it will, by eliciting comment, criticism, and perhaps correction, help to make the larger work of more permanent value. Any assistance to this end will be gratefully accepted by the author.

EDWARD J. NOLAN

The Academy of Natural Sciences of Philadelphia, November, 1909. 



\title{
The Academy of Natural Sciences of Philadelphia
}

\author{
By EDWARD J. NOLAN, M.D.
}

As for the Corruptions and Moths of History, which are Epitomes, the use of them deserveth to be banished as all men of sound judgment have confessed.-Bacon, "Advancement of Learning."

A LTHOUGH at the beginning of the nineteenth century Philadelphia was acknowledged to be the center of scientific, if not of literary culture in America, there were not many societies in the city devoted to scientific research. The American Philosophical Society had, indeed, established for itself an honorable position in the learned world, but membership was scarcely aspired to by those who had no right in any sense to consider themselves philosophers. The "Botanical Society, held at Philadelphia," had been founded in 1806, the name being changed the following year to the "Philadelphia Linnæan Society." It had a brief and uneventful existence and is at present remembered from the publication of an essay by Benjamin Smith Barton, entitled "Discourse on some Principal Desiderata in Natural History."

There were but few who cared anything about the natural sciences, and these had to contend with many difficulties. Neither cabinets to awaken curiosity nor libraries to satisfy it were in existence. There were two or three collections of minerals belonging to gentlemen who had brought them from Europe, but they were not accessible to the public.

A few young men in the city were, however, interested in the study of nature. They were all engaged during the day in making a living, and they must have found that occasional gossip in places of resort available to those of their social condition would not help them much in the search for exact knowledge.

After one of these accidental meetings early in 1812, John Speakman suggested to his friend Jacob Gilliams that if their associates could come together at stated times where they would be free from interruption and could compare notes as to what they supposed they knew, they would secure more pleasure and profit than by desultory talk. Gilliams agreed with him, and before they 
separated it was decided to invite such friends as might be favorable to the formation of a society to meet at Speakman's house the following Saturday night.

In accordance with this agreement Doctors Gerard Troost and Camillus Macnahon Mann, with Jacob Gilliams, John Shinn, Jr., and Nicholas S. Parmentier, met at the house of Mr. Speakman, on the nortliwest corner of Market and Second Streets, on Saturday evening, January 25, 1812. Mr. Speakman acted as chairman, and Dr. Mann as secretary. The minutes are described as those of "a meeting of gentlemen, friends of science and of rational disposure of leisure moments," and it was agreed that the exclusive object of the society should be the cultivation of the natural sciences.

This was the humble origin of The Academy of Natural Sciences of Philadelphia. Although there is abundant evidence in the records and in tradition that the founders took themselves seriously and were conscious of the dignity of their undertaking, it is scarcely conceivable that they could have anticipated the future development of their society into one of the most active and influential scientific associations of the world.

In order not to be a burden on Mr. Speakman's hospitality, the next two or three meetings were held at a public house on Market, or High Street, near the corner of Franklin Place, known as Mercer's Cake Shop. The title, Academy of Natural Sciences, was employed for the first time in the minutes of March 21, 1812, and was suggested opportunely by Dr. Samuel Jackson, of the University of Pennsylvania. He had not joined the society because, it is said, he feared that in the estimation of the public all its members would be considered, however unjustly, as lacking in proper respect for religion, a supposition which might be detrimental to a physician at the outset of his career. It was decided that the origin of the Academy should date from that session and that in subsequent years the anniversary should be observed on that day.

At this meeting Thomas Say was chosen a member, and it was determined that, although he had not attended the initial meetings, his name should be enrolled as one of the founders, who are, therefore, recorded as being John Speakman, ${ }^{1}$ Jacob Gilliams, ${ }^{1}$ John Shinn, Jr., Nicholas Parmentier, Dr. Gerard Troost, ${ }^{1}$ Dr. Camillus Macmahon Mann and Thomas Say. ${ }^{1}$ It was John Speakman and

1 Portraits of these are hung in the library. 


\section{The Academy of Natural Sciences}

Jacob Gilliams, however, who had issued the invitation for the preliminary meeting and the conclusion is a just one that the foundation of the Academy is ascribable to these two men.

John Speakman was born in Bucks County, Pennsylvania, and belonged to the religious society of Friends. His apothecary shop at the northwest corner of Second and Market Streets was a center of literary and scientific gossip. He was for a time in disastrous partnership with Say and was ever ready to do all the work of the shop so as to enable his friend to devote almost his entire time to the service of science. Through the endorsement of unreliable friends the firm came to an unfortunate end, the partners retaining scarcely anything for themselves. As late as $1839 \mathrm{Mr}$. Speakman, at a considerable sacrifice of his private interests, visited Mr. Maclure in Mexico, where he spent several months for the benefit of the Academy.

Mr. Jacob Gilliams was a native of Philadelphia and a leading dentist of the day. He was an intimate associate of Thomas Say and Alexander Wilson, and when the latter was engaged on his American Ornithology the three friends were frequent visitors to Mr. William Bartram at his house attached to the garden which has now become classic ground.

Mr. John Shinn, Jr., was a native of New Jersey. He was employed as a manufacturing chemist. Soon after the Academy was established in the new hall in Gilliams' Court he delivered a course of lectures on chemistry, the first given under the auspices of the society.

Mr. Nicholas S. Parmentier was born in France. He was a distiller and manufacturer of spermaceti oil. He removed to Florida.

Gerard Troost ${ }^{2}$ was the first President of the Academy and served efficiently until $181 \%$ when he was succeeded by Mr. Maclure. He was born in Bois-le-Duc in Holland and educated as a pharmacist and chemist. He settled in Philadelphia in 1810. In 1815 and 1816 he engaged in the manufacture of alum on the Magothy River in Maryland. On his return to the city he delivered lectures on mineralogy in the Philadelphia Museum and the College of Plarmacy. After spending two years with his friend Maclure at New Harmony, Ind., he was elected, in 1828, Professor of Chemistry,

2 University of Tennessee, Bulletin of Information, v., 6, Jan., 1907. 
Geology and Mineralogy in the University of Nashville, retaining the position until his death August 1\%, 1850. During his incumbency he served as State Geologist of Tennessee until the office was abolished in 1849 .

The first Recording Secretary, Dr. Camillus Macmahon Mann, was born in Ireland. He was "out" in the rebellion of 1798. After a stay in France he sought refuge in the United States, living for a time in Philadelphia, and later edited a paper in Baltimore. The date of his death is uncertain.

The presence of Thomas Say at a meeting is first recorded on Thursday, April 16, 1812. Henceforth, except when away from the city, he was rarely absent from a session of the society. It may be claimed that the continued existence of the Academy was in great measure due to his devotion and the dignity he was able to give the proceedings by the high character of his scientific work. After the failure of the firm of Speakman and Say he resided for a time in the hall of the Academy, accommodating himself heroically to his exceedingly cramped means. In 1825 he accompanied Mr. Maclure to New Harmony. The communistic experiment in which they were engaged having proved a failure he accompanied Mr. Maclure to Mexico. He remained there for twelve months and was then compelled by business engagements to return to New Harmony where he died October 10, 1834, in his forty-seventh year. Much the greater part of his work was completed before he left Philadelphia for the West. In his new home, however, his business engagements evidently did not take up all his time for he issued there six numbers of the American Conchology and several papers, including two in the Annals of the Maclurean Lyceum.

Say was a born naturalist. He troubled himself but little about relationships and classification, confining himself almost entirely to the determination of specific distinctions of which he had an unusually acute perception. His reports of original researches were the first to replace the reading of extracts from encyclopædias or journals, which formed the attraction at the earlier meetings. ${ }^{3}$

About the first of April a small room on the second floor of a

3 An appreciative biography of Say, by George Ord, is published in connection with The Complete Writings of Thomas Say on the Entomology of North America, edited by John L. Le Conte, M.D. Another by Benjamin Horner Coates was issued under the auspices of the Academy in 1835. 



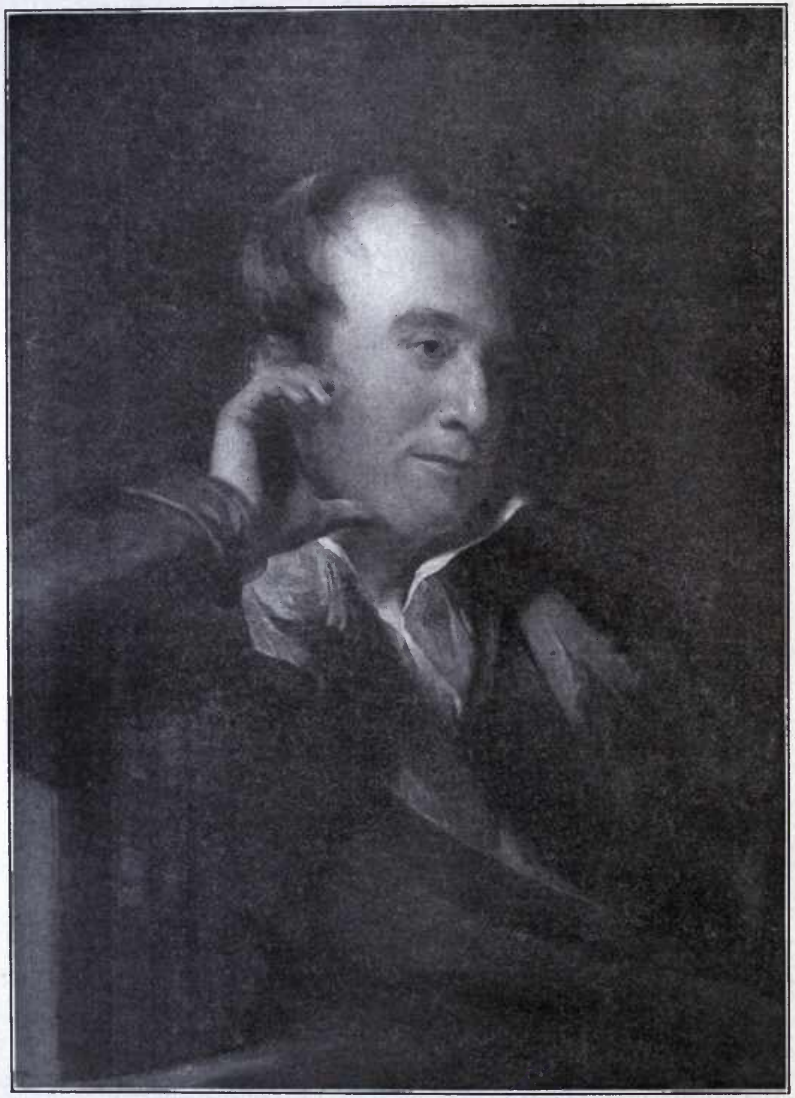

WILLIAM MACLURE, 1763-1840. 
house on the east side of Second Street, then No. 121, near Race Street, was rented. Here the nucleus of the present library and museum was formed. Each member gave something, and although the "display of objects of science was calculated rather to excite merriment than to procure respect" the result formed the germ of the superb library and museum which have given the Academy distinction among scientific societies.

On the fifteenth of August, 1812, a collection of minerals containing about 2000 specimens, previously purchased from Dr. Seybert for $\$ 750$ by Mr. Speakman, was acquired by the society, and soon after Dr. 'Troost delivered a course of lectures on mineralogy to the members and others. It is a tradition that the necessity of discharging the indebtedness incurred by the purchase of the Seybert minerals, was a bond of union during the first year or two of struggle and discouragement.

The collections, meager as they were, soon required more room and in September of the same year they were removed to apartments in the upper part of a house on the west side of Second Street, then No. 78, north of Arch. These quarters were called the Hall of the Academy. So little interest had the new society enlisted that at the close of its first year it consisted of but fourteen members and thirty-three correspondents.

During the following two years the museum and library increased more rapidly. Lectures on entomology were delivered by Mr. Say and on botany by Drs. Waterhouse and Barnes.

At the beginning of 1815 increased accommodation was again necessary and Mr. Gilliams built a hall on a vacant lot in the rear of his father's house on the north side of Arch Street east of Second. The collections were removed to it in July. The first period of the Academy's existence extended from its foundation to this, the first exclusive occupancy of a building.

As far as regards the permanency and prosperity of the society the most important event of these years was the election to membership in June, 1812, of William Maclure without whose help it would probably not have been possible to prolong its existence.

In 1816, a constitution was adopted and the society was legally incorporated the following year.

At the instance mainly of Mr. Maclure the Academy decided on the publication of a Journal, the first number of which was placed before the meeting held May 20,181\%. The first volume was issued 
under great discouragement and the publication was suspended until 1821 when, owing to the industry and zeal of Dr. Isaac Hays, it was continued without incurring further indebtedness.

In November, 1817, Standing Committees on Zoölogy, Botany, Mineralogy and Geology were appointed for the first time.

Progress was not very rapid, yet at the close of 1820 the question of enlarged accommodation once more presented itself for consideration. At that time there were one hundred members and one hundred and ninety correspondents on the roll. A committee was appointed in 1823 to consider the best means of obtaining additional room. It was not, however, until 1826 that a lot of ground and a building at the southeast corner of Twelfth and Sansom Streets (then George's Street) were purchased for $\$ 4,300$. The building had been used for several years as a place of worship by a society of Swedenborgians, and to fit it for the purposes of the Academy an expenditure of $\$ 1,700$ was required. A debt of $\$ 3,000$ was created and up to August, $183 \%$, only $\$ 300$ of the amount had been paid off. Mr. Maclure then gave $\$ 5,000$, the debt was liquidated and $\$ 2,300$ were placed at interest for the current needs of the institution, the first time in its history that it was in possession of such a surplas.

A first meeting was held in the new hall on May 9, 1826. In 1828, the museum was open to the public. Since that time admission to the collections under varying conditions, has been an important factor in the educational resources of the city.

For the next fourteen years the prosperity of the Academy was uninterrupted, although its resources remained extremely meager compared with the amount and character of the work accomplished. William Maclure, because of his active interest in the society, richly deserved the compliment of an annual re-election as President, although his prolonged and frequent absence from the city made it impossible for him to discharge the duties of the office. George Ord, as Vice-President, acted as his zealous and efficient substitute until 1834 when he was succeeded by John Price Wetherill. The other Vice-President, William Hembel, was too deaf to act as presiding officer.

Among the successors of Dr. Mann, the first Recording Secretary, William Hippolyte Keating is distinguished for his faithfulness and efficiency. He served from January, 1822, to December, 1825, and has left two annual reports which are of interest as indicating specifically the value of the work the Academy was then doing. He 


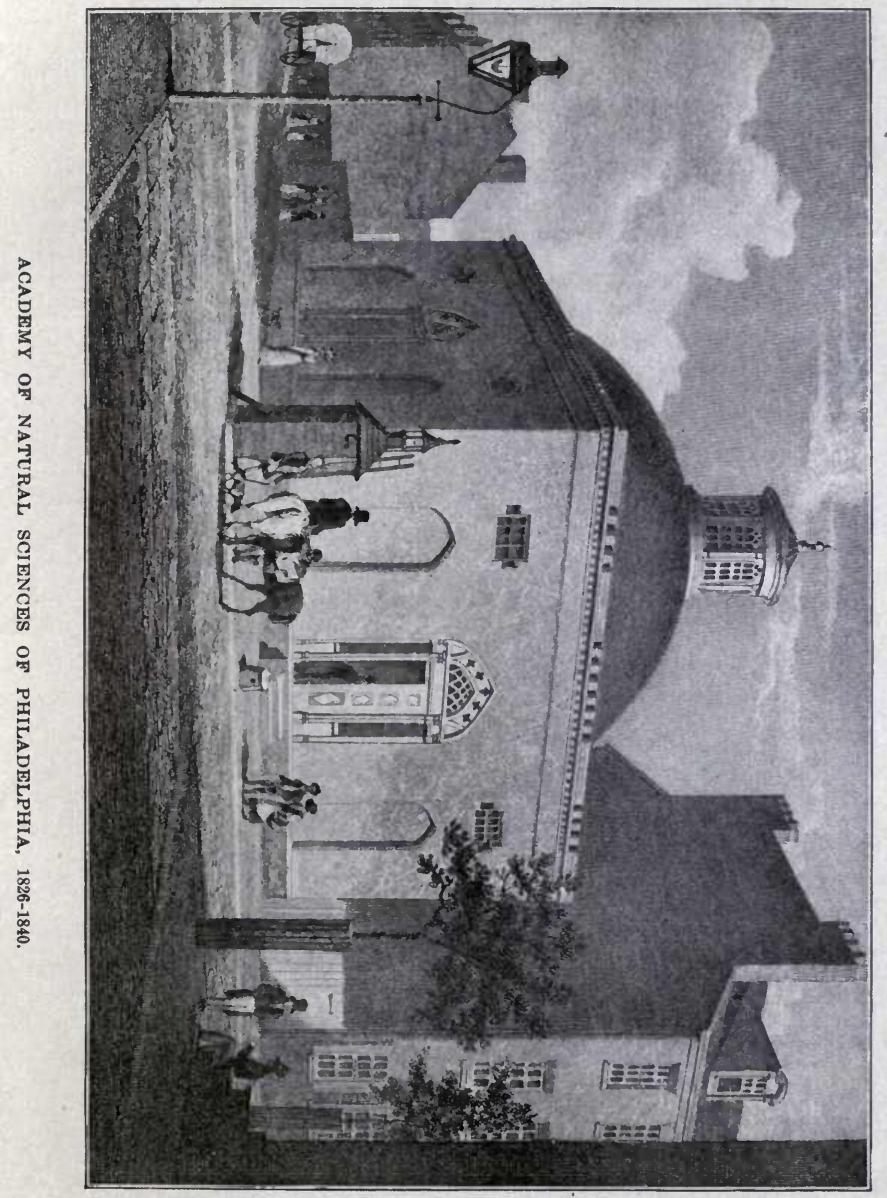




\section{The Academy of Natural Sciences}

relinquished the office because of removal from the city and was succeeded by Dr. Samuel George Morton who served until 1829.

The necessity for increased room becoming yearly more pressing, a lot at the northwest corner of Broad and Sansom Streets was bought on the twenty-second of April, 1839, for $\$ 13,333$. On Saturday the twentieth of May, the corner-stone of a new building was laid with the usual ceremonies by Vice-Presidents William Hembel and John Price Wetherill. An eloquent address was made on the occasion by Walter R. Johnson ${ }^{4}$ who had been one of the most active members of the society since his election in 182\%. He had been a Curator in 1836 and $\mathbf{1 8 3 7}$ and subsequently served as Corresponding Secretary from 1841 to 1848 . The building was forty-five feet front on Broad Street by eighty-five feet deep on Sansom with an elevation of fifty-five feet. It at first consisted of a single saloon with two ranges of galleries, beneath which, in the basement, was a lecture room to accommodate five hundred people. The value of the premises at the corner of Twelfth and Sansom Streets had appreciated and the property was sold to William R. Hanson for $\$ 10,950$. The means for the erection of the new hall were, however, chiefly derived from William Maclure who subscribed toward the object $\$ 20,000$. The building fund was largely augmented by liberal subscriptions from members and others interested in science.

The transfer of the collections and library was made at a cost of $\$ 34$, several of the members giving their time and strength to the service so as to lower the expense and save time. One of the most active in this work and in the accumulation of the building fund was William S. Vaux who had been elected a member in 1834. During the rest of his life he gave devoted attention to the economic interests of the Academy, serving continuously as Curator from 1838, and as Vice-President from 1860, with a brief interval, until his death in 1882. He also rendered indispensable service as a member of the Publication Committee from 1840 and as treasurer of the Board of Trustees of the Building Fund from its organization in January, $186 \%$.

The books and specimens were placed in the saloon on the second floor and here the first meeting was held on the 18th of February, 1840.

4 Nat. Encycl. of Am. Biogr ${ }_{\phi}$ xii, 260. Barnard's Am. Journ. Education, Dec., 1858. 
The death of William Maclure 5 on the 23d of March, 1840, inflicted on the society the greatest loss it had yet sustained. In addition to his large pecuniary contributions, he had given in $\mathbf{1 8 3 5}$ a selection from his library in New Harmony. The transfer of the collection, amounting to 2,259 volumes and an extensive series of maps and charts, had been safely accomplished by Charles Pickering, the distinguished author of the Chronological History of Plants, who was Librarian of the Academy from 1829 to 1833. He had also conducted the transfer and arrangement of a great number of plants bequeathed by the Rev. Lewis David von Schweinitz, who died in 1834.

Mr. Maclure was succeeded in the Presidency by William Hembel $^{6}$ who had been elected a member in 1825 . He held the office from December, 1840, until December, 1849. His administration was uneventful. In the hope of being able to remedy impaired hearing resulting from an attack of scarlet fever he had studied medicine in the University of Pennsylvania but did not graduate.

Dr. Morton announced to the meeting held June 16, 1840, that a bill for the perpetual exemption of the property of the Academy from taxation had passed both houses of the Legislature.

The first annual election in the new building at Broad and Sansom Streets resulted as follows: President, William Hembel; Vice-Presidents, John Price Wetherill, Samuel Geo. Morton, M.D.; Corresponding Secretary, Robert Bridges, M.D.; Recording Secretary, A. Denman Chaloner, M.D.; Librarian, A. L. Elwyn, M.D.; Curators, William S. Vaux, John S. Phillips, Robert Pearsall, George C. Leib, M.D.

In March, 1841, the publication of the Proceedings was commenced. The sessions of the Academy were then and until May, 1903, held every 'Tuesday evening throughout the year.

A most important event in the history of the society was the election to membership on July 29, 1845, of Dr. Joseph Leidy. He published the first of a brilliant series of contributions to natural history in the Proceedings a couple of months later and for the succeeding forty-six years he exerted a most active influence on the well-being of the institution in every department of its administra-

5 A Memoir of William Maclure, by Samuel George Morton, M.D. Published by the Academy, 1841.

6 Simpson's Lives of Eminent Philadelphians, 1859, p. 515. 


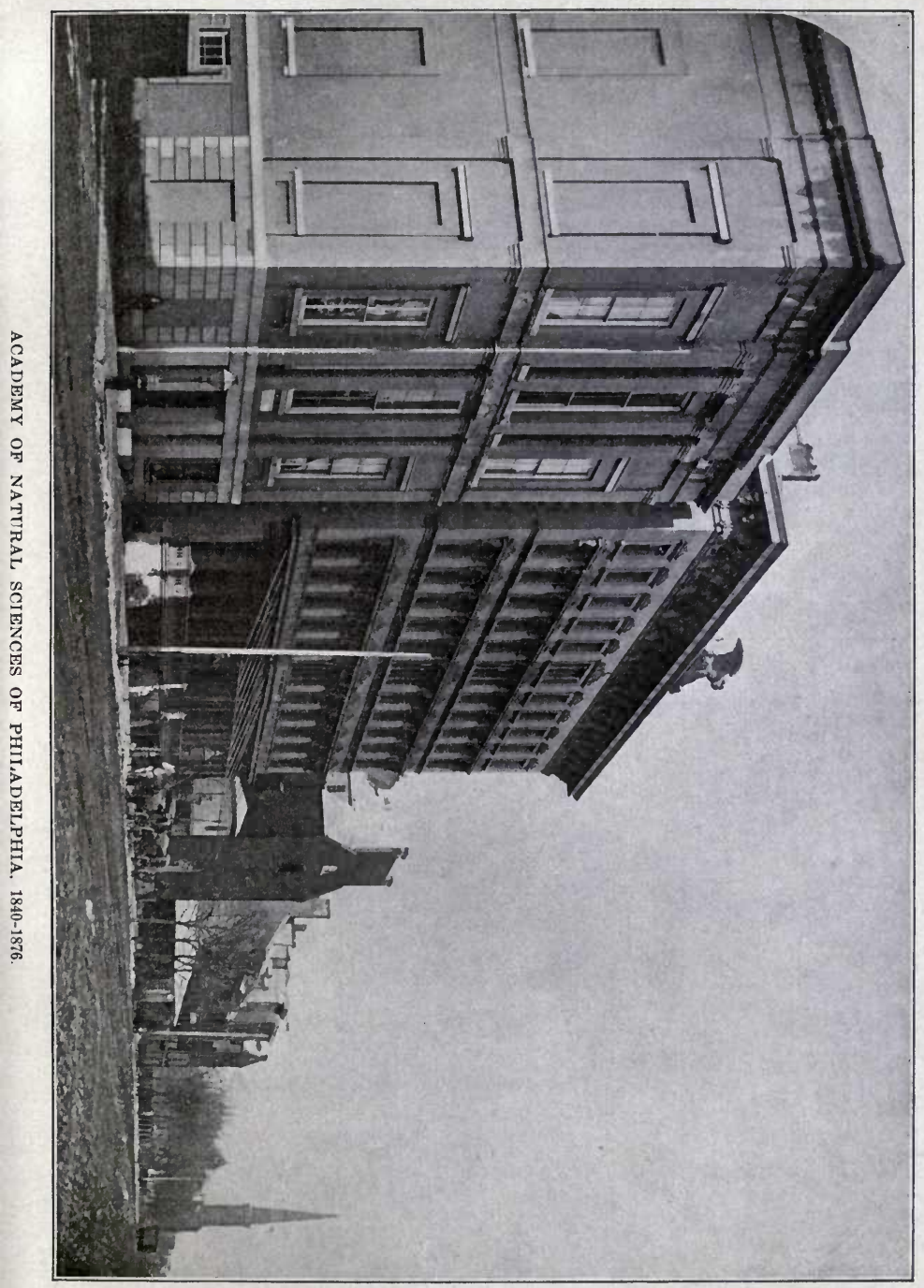



tion until, to the community at large, the names of Leidy and the Academy were inseparably associated.

At the stated meeting of June 30,1846, Dr. Morton announced that Dr. Thomas B. Wilson, having purchased the famous collection of birds of the Duc de Rivoli, embracing 10,000 specimens mounted and named, was desirous of arranging them in the museum. In furtherance of Dr. Wilson's wishes the building was extended thirty feet westward covering all the ground then at the disposal of the society. The library was moved from the second floor to the new room at the west end of the basement and the first meeting was held in it May 4, 184\%. Vice-President Morton made a brief address of welcome and congratulation on taking the chair. He alluded feelingly to the services of those who had sustained the burden during the days of struggle and uncertainty and gave credit to those who were then devoted to the interests of the Academy, alluding especially to Dr. Wilson who had paid the entire cost of the extension to the building but, in deference to his modesty, without mentioning his name. Dr. Wilson's entire collection of birds, amounting to 26,000 mounted specimens and 2,000 skins, until then on deposit, was presented outright in 1860 . The ornithological collection formed the most attractive feature of the museum, and for years gave it distinction in the appreciation of the public.

While the collection of birds was Dr. Wilson's most striking gift, every department of the museum and library received important additions from him. No other benefactor of the Academy has demonstrated his interest in its welfare with such active personal exertion or with such self-sacrificing labor. His name, therefore, should be among the first of those who deserve the gratitude of the society. ${ }^{7}$

A second series of the Journal in quarto was begun in December, 184\%, mainly through the influence and on the urging of Dr. Wilson who subsequently contributed liberally to the expenses of illustration, especially of the fine colored plates of Cassin's descriptions of new species of birds.

In 1848 , there were on the lists of the society 245 members and 520 correspondents. The most active workers were Samuel George Morton, John Cassin, Joseph Leidy, William S. Vaux, Robert

7 A Memoir of Thomas Bellerby Wilson, M.D. Proc. Ent. Soc. of Phila., v., 1865. 
Bridges, John Phillips, William Gambel, Timothy Abbott Conrad, and Samuel Stehman Haldeman.

At the close of $1849, \mathrm{Mr}$. Hembel declined a renomination for the Presidency. He was succeeded by Dr. Morton who had, with few exceptions, presided at the meetings during the entire incumbency of his predecessor. Dr. Morton's position as Vice-President was filled by the election of Dr. R. Egglesfield Griffith, the accomplished author of the Medical Botany. He died in 1850 .

The election of Dr. Morton to the Presidency was a fitting recognition, not only of more than a quarter of a century's devoted service, but also of his distinguished rank as one of the world's most accomplished ethnologists. He was to enjoy the well-merited honor, which was the ultimate expression of the Academy's appreciation of his work, for less than eighteen months. He presided at a meeting for the last time on May 6, 1851, and died on the 15th of that month in his fiftieth year, after an illness of four days. His first work was in geology but his magnum opus, the Crania Americana, was published in 1839 and has been properly described as a lasting monument to his learning, energy and ability. His last paper was on the size of the brain in various races of man and in support of his belief in the plurality of origin of mankind, a doctrine to which he gave unfaltering support. 8

Dr. Morton was succeeded in the Presidency by George Ord. He had served as Vice-President from 1816 to 1834 and as Curator during 1816 and 181\%. He belonged to the old-fashioned type of naturalist which has now almost entirely disappeared. His favorite subjects of study were birds and mammals although he did not confine his attention entirely to them. He acted as the literary executor of his friend Alexander Wilson. His contribution to Guthrie's Geography is regarded as the first systematic work on the zoölogy of North America by an American. His biographies of Wilson and Say are specimens of elegant English and prove him to have had what his friend Charles Waterton called "a polished mind." Although he had declared as far back as 1841 that he was compelled by the encroaching infirmities of age to abandon his nature studies and devote himself to more sedentary occupations, he served the society faithfully as presiding. officer until December, 1858, when,

8 A Memoir of Samuel George Morton, by Charles D. Meigs, M.D. Read November 6, 1851, and published by direction of the Academy, Philadelphia, 1851. 
declining a renomination, he was succeeded by Isaac Lea. Mr. Ord died January $23,1866 .^{9}$

The anniversary of the founding of the Academy was celebrated in 1854. On the evening of March 20th, William Parker Foulke delivered an appropriate address in the Hall of the University of Pennsylvania, and the following evening more than one hundred members and correspondents, with a few distinguished guests, dined in the hall of the Musical Fund Society, the occasion being long remembered as an unusually pleasant one.

In 1855 , the building was again enlarged by the erection of an additional story of twenty-four feet in height at a cost of $\$ 12,263$, the entire amount being secured in subscriptions by a committee of which Mr. William S. Vaux was the energetic and efficient chairman.

The specimens in the apartment fronting on Broad Street, at first designed as a lecture room, were now removed upstairs and the growing library was extended into the room thus vacated which was used subsequently as the place of meeting. The western room in which the meetings had been held was later divided by a galleried partition, thus affording additional space for shelving.

In 1858, the recently formed Biological Society became the Biological Department of the Academy, Dr. Leidy being the first Director. Valuable contributions were made for the next three years to the separately paged Proceedings by S. Weir Mitchell, Henry Hartshorne, J. Cheston Morris, William A. Hammond, Isaac I. Hayes, J. J. Woodward and the Director. More pressing matters engaged the attention of many of the members on the breaking out of the war, so that the meetings were suspended and not resumed until 1868, when renewed life was acquired by union with the recently organized Microscopical Society of Philadelphia, the combination being known as the Biological and Microscopical Section of the Academy.

As a presiding officer Dr. Lea was dignified and genial, greatly enjoying the exchange of opinions with those brought together each succeeding Tuesday evening. He imparted to the meetings more than ever the character of conversazioni, frequently dropping the gavel long after the appointed time. He died December 8, 1886.10 In 1860, the children of the late Augustus E. Jessup, in fulfil-

9 George Ord, by Samuel N. Rhoads. Cassinia, No. 12, 1908.

10 The Published Writings of Isaac Lea, LL.D. By Newton Pratt Scudder. Bulletin of the U. S. National Museum, No. 23. 
ment of his intention, announced that they would pay $\$ 120$ per annum toward the expenses of publication and $\$ 480$ per annum for the assistance of poor young men desiring to study natural history. The sums named were regularly paid until February, 1872, when $\$ 10,000$ in bonds were transferred to the Academy. Mrs. Clara J. Moore, in 1888 , added $\$ 5,000$ to the fund and, in 1893 , she gave $\$ 5,000$ for the assistance of young women similarly inclined. Sixtynine men and four women have been assisted by the endowment, some of them attaining dignified positions as teachers, geologists, biologists and authors.

The same year the Academy lost the services of the Treasurer, George W. Carpenter, who had served in that capacity most discreetly for thirty-four years. $\mathrm{He}$ was ever generous in his encouragement of young naturalists, Mr. Thomas Meehan, for example, being always warm in his acknowledgement of indebtedness to him.

The Academy entered on its second half century under the brightest prospects and with a most gratifying record of honorable achievements. The year 1862 was made notable by the work of illustrious veterans who were still active, and by what there was reason to expect from their successors. But few of the great collections which have since come into prominence were in existence. The Smithsonian Institution was then rather a distributing agency than a storehouse of scientific material. The United States Government had not become, through the Agricultural Department, the National Museum, the Fish Commission and the Geological Surveys, one of the largest publishing concerns in the world, and a formidable rival in the publication of scientific matter, so that the work of Gill, Meek, Hayden, Coues, Stimpson, Kennicott, Yarrow and others in Washington and elsewhere, was issued promptly and accurately in the pages of the Proceedings and Journal.

Leidy had suspended for a time his delightful field and laboratory notes and was pursuing his paleontological studies in a little dark and dusty room on the first floor of the museum. These he continued until driven out of the field by the wrangling of Cope and Marsh, when his microscopic studies were carried on more comfortably at home.

John Cassin ${ }^{11}$ had held for years such undisputed sway over the

11 John Cassin, by Witmer Stone. Cassinia I, pp. 1-7. 
collection of birds as to be somewhat jealous of his authority as Ornithological Curator. Daniel Giraud Elliot and others desiring access to the specimens for purposes of study found him ready with most generous assistance, but interference in the administration of the department, as was once attempted by Dr. Heerman, the cataloguer of the oölogical collection, was sternly and effectively resented. The western room of the library was filled with trays of mounted birds and scores of volumes which no one dared to touch. Books and specimens, although somewhat the worse for dust, were made good use of by the autocrat, especially on Sundays, for the exigencies of breadwinning left him but little time for his favorite studies during the week.

The genial old Frenchman, Elias Durand, ${ }^{12}$ had charge of the herbarium and was just then much perturbed by the blunders of S. B. Buckley in his papers on the plants of Texas. These were later unsparingly criticised by Gray.

Lea was reading at the meetings the prodromi of the papers to be afterwards printed in extenso in the Journal and, it must be confessed, not contributing greatly thereby to the interest of the sessions. The sound of the fierce battle between him and Conrad had died away and the latter, as efficiently as his dyspepsia would allow, was describing fossil shells and making autograph drawings on stone of his new species, his activity being greatly stimulated by the facilities for publication supplied by the newly started American Journal of Conchology.

George W. Tryon, Jr., ${ }^{13}$ the devoted editor and proprietor of the new journal, was an indefatigable worker and gave up his interest in a lucrative business to devote himself to science. Before doing so he devoted every spare moment to his conchological work and on meeting nights and holidays would be found at his preëmpted post in the library with trays of shells and piles of books preparing his lists and monographs. He started the American Journal of Conchology in 1865 and carried it successfully through seven volumes. In 1879 he published the first number of the Manual of Conchology, a work to which his future scientific labors were almost entirely confined. The series has been continued by the

12 Obituary Notice of Elias Durand, by Thomas Meehan, Proceedings A. N. S. P., 1873, pp. 355-359.

13 A Biographical Notice of George W. Tryon, Jr., by W. S. W. Ruschenberger, M.D. Proceedings A. N. S. P. 1888, pp. 399-418. 
Academy since Tryon's death in 1888, under the able editorship of Dr. Henry A. Pilsbry, the value of whose conchological work has received the most cordial recognition. Mr. Tryon's business training enabled him to actually secure a revenue from his two unpromising ventures, which, with much more, he bequeathed to his favorite department. In quite a special sense, therefore, his work continues.

Much the greater part of Cope's time was, at this period, devoted to the study of herpetology, his work being done in a small room in the northeast corner of the first gallery. Cope's contributions to science, his paleontological work especially, lent brilliancy to the Proceedings and Journal and as time progressed entitled him to be regarded as the greatest naturalist born on American soil. In his relations to the administrative affairs of the Academy, he was ever a storm center, absolutely a law unto himself, and so divergent were his theories and methods from those entertained by Dr. Leidy and his other associates, that for years before his death in $189 \%$, he had no official connection with the society, although his interest in the meetings was maintained and the provisions of his will give evidence that, through all the disagreements and in spite of them, he retained confidence in its usefulness and was, perhaps, after all not entirely opposed to its methods. He bequeathed to the Academy about 8,000 valuable specimens of mammals, birds, reptiles and fishes and the fund arising from the sale of his paleontological collections after the payment of certain legacies.

Dr. James Aitken Meigs had taken up the work of Samuel George Morton and was giving all the time he could spare from a rapidly growing practice to the study of ethnology, with the fine results recorded in the Proceedings.

John Hamilton Slack, a man of extraordinary versatility, in a little room directly under Cope's, was studying the mammals and laying ambitious plans for a monograph of the monkeys, which, it is to be regretted, resulted in nothing more than a sixteen page contribution to the Proceedings. He was a frequent visitor to the library and by his accomplishments gave brightness and variety to the dullest days.

William M. Gabb, during his term as one of the Jessup Fund students, had fitted himself for the work accomplished later in connection with the Geological Survey of California and as Director of the surrey of San Domingo. 
The first recipient of benefits from the Jessup endowment was Charles Conrad Abbott, then engaged in the study of ichthyology, but later recognized as an authority on the Stone Age in America and as the author of graceful contributions to the literature of nature study.

Harrison Allen ${ }^{14}$ had begun his fine work on the bats and had contributed his first papers to the Proceedings for 1861. They were, in common with those prepared by him in later years, characterized by painstaking accuracy and remain of permanent value, conscientiousness being the keynote of the author's character and work.

John L. Le Conte ${ }^{15}$ was adding to his reputation as one of the most accomplished of American naturalists by a series of papers on the coleoptera. From him his friend and protégé, George H. Horn, ${ }^{16}$ was drawing the inspiration that enabled him to secure a distinguished position in the same department of science.

Thomas Meehan ${ }^{17}$ had been elected a member ten years before and was contributing to the Proceedings the results of his observations on the physiology of plants, continued until his death in 1901. He was indefatigable as Conservator of the Botanical Section, and gave much time and labor, even when suffering from the illness which proved fatal, to the increase and care of the herbarium. He was an acute observer and graceful recorder of the life histories of plants, and it is far from being to his discredit that he never, as far as known, thought it worth while to describe a new species.

John Warner's communications on the mathematics of organic morphology gave a novel interest to several of the meetings,

14 Proceedings of a meeting of the Academy held in commemoration of Harrison Allen, M.D., and George H. Horn, M.D., Proceedings of the Academy, 1897, pp. 505-535. Harrison Allen, 1841-1897, by Burt G. Wilder. Association of American Anatomists, December 28, 1897.

15 Biographical Sketch of John Lawrence Le Conte, by S. H. Scudder. Trans. Am. Ent. Soc., xi, 1883-84, pp. 1-27. Sketch of John L. Le Conte, by Jos. P. Lesley, and Memoir, by George H. Horn, M.D. Proc. Am. Philos. Soc., xxi, 1883, pp. 291-299.

16 Proceedings of memorial meeting, Proc. A. N. S.,.1897, pp. 505-535; A Biographical Notice of George Henry Horn, by Philip P. Calvert. Transactions Amer. Ent. Soc., xxv, 1898.

17 "The Botanists of Philadelphia and Their Work," by John W. Harshberger, Ph.D., 1899, pp. 249-256. 
delivered as they were with a quaint earnestness which held the attention even of those unable to follow his abstract deductions.

These were the men who were actually engaged in original scientific work on and about the fiftieth birthday of the Academy, in connection with its library and museum. Their contributions to knowledge were published in the Proceedings and Journal, which were additionally reinforced by contributions from most of the leading naturalists of America.

Dr. Lea declined a re-election in 1863 , and Dr. Wilson very reluctantly and on the persistent urging of nearly every one he met during his visits to the premises, allowed himself to be placed in nomination, and was, of course, unanimously elected at the annual meeting of that year. His term of office was the briefest in the history of the Academy. He was not altogether satisfied with the conduct of the entomological department, and had, with characteristic zeal, allied himself with the American Entomological Society, which had been founded in 1859 and incorporated in 1863 . His sympathies during the war were distinctly Southern and therefore not in harmony with the rather aggressive patriotism of the majority of his fellow-members. Moreover, his desire to remain in retirement and to avoid any expression of gratitude for his enormous benefits to the society made his position as President distasteful to him. As a matter of fact he had not presided at a single meeting when, on June 28, 1864, he sent in his resignation.

Dr. Wilson was succeeded by Dr. Robert Bridges, ${ }^{18}$ who had been elected to membership in 1835 . There probably has never been one among those devoted unobtrusively to the interests of the society who rendered more efficient service than Dr. Bridges. He had served at various times as Librarian, Recording Secretary, Corresponding Secretary, Auditor and Vice-President, and did effective work on numerous standing and special committees, including those on the Library, Publications, Finance, Botany, Entomology, Herpetology and Ichthyology, Physics and Chemistry. His unassuming modesty was like that of his predecessor, and after one year in office he declined a re-election, and was

18 Biographical Notice of Dr. Robert Bridges, by W. S. W. Ruschenberger, M.D. Proceedings Am. Phil. Soc., xxi, 1884, pp. 427-447. Proceedings of the Academy, 1882, pp. 226-230. 



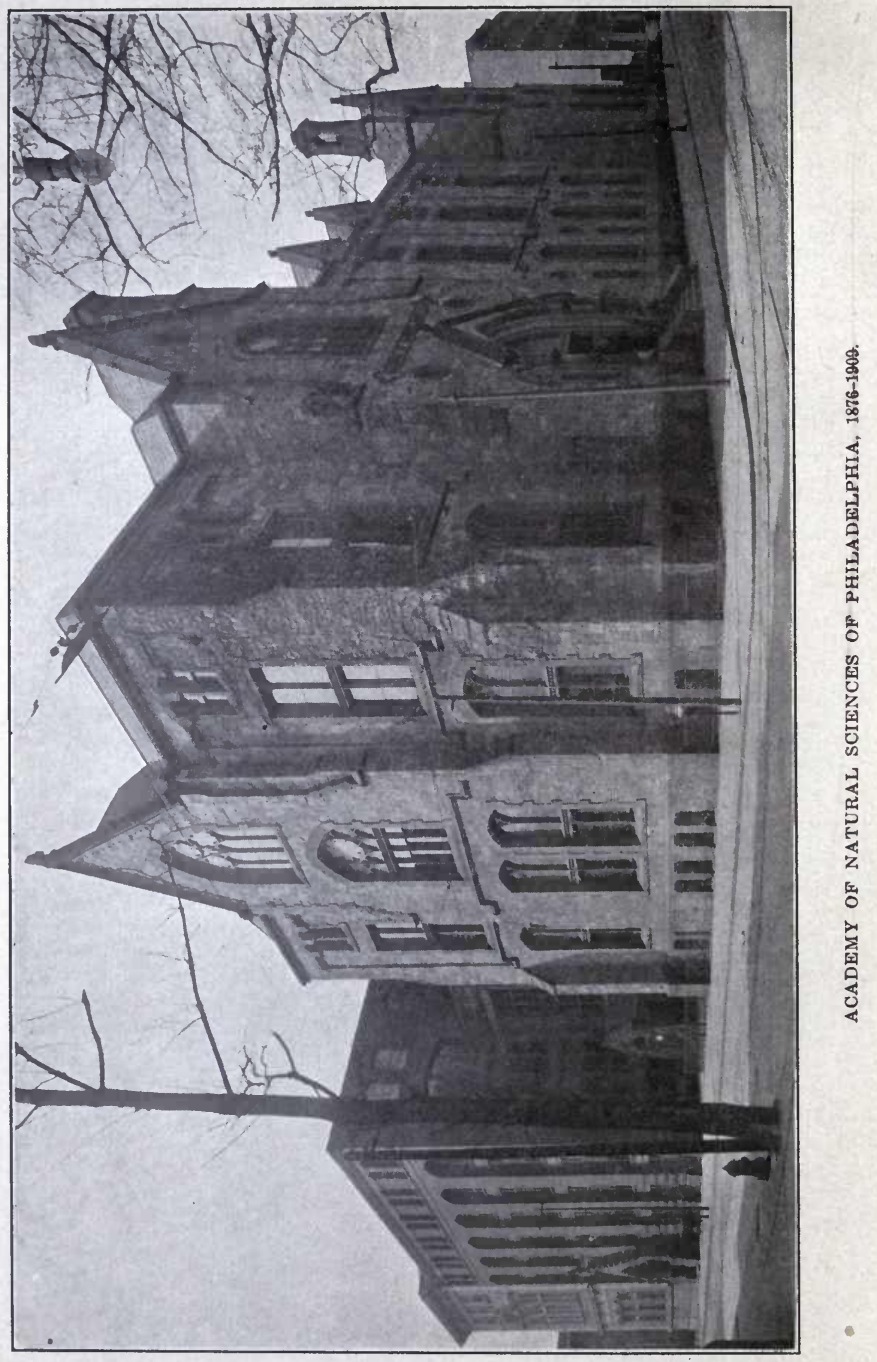


succeeded by Dr. Isaac Hays 19 whose early services to the society, especially as Curator and Chairman of the Publication Committee, established the propriety of his election, for there is no doubt that to his zeal and ability alone was due the continuation of the first series of the Journal. He presided with dignity and efficiency for four years, and was then succeeded by Dr. William S. W. Ruschenberger.

Notwithstanding the space provided by the additional story completed in 1855, the need of more room for the arrangement of the collections was again becoming urgent. A committee of forty was appointed in December, 1865, to solicit subscriptions for the erection of a fire-proof building on a lot of ground not less than three times the size of the one then occupied and as close to it as possible. In January, 186\%, a Board of Trustees of the Building Fund was elected by the subscribers, Dr. Ruschenberger being made Chairman, George W. Tryon, Jr., Secretary, and William S. Vaux, Treasurer. Without the least forgetfulness of the loyal service and the courageous perseverance in the face of many discouragements of the other members of the Board, it may be claimed with justice that to these three men was due the success of the undertaking.

After an ineffectual attempt to secure possession of one of the four Penn Squares at the intersection of Broad and Market Streets, and the rejection of propositions to move to Fairmount Park and elsewhere equally undesirable, a lot of ground of adequate size on the southwest corner of Nineteenth and Race Streets, was purchased in 1868 for $\$ 65,298$. A plan submitted by James H. Windrim, in competition with Messrs. Frazer, Furness and Hewit, and John C. Trautwine, was adopted, and Mr. Windrim was appointed architect. It was not, however, until May, 1872 , that the Building Committee was authorized to commence the edifice. The cornerstone was laid at noon on Wednesday, October 30 , addresses being delivered by Dr. Ruschenberger, Rev. Elias R. Beadle, Dr. J. Aitken Meigs, Dr. Horatio C. Wood and Rev. George Dana Boardman.

So untiring had Dr. Ruschenberger been in the fulfillment of the trust confided to him as Chairman of the Board of Trustees

19 Memoir of Isaac Hays, M.D., by Alfred Stille, M.D. Trans. Col. Phys. Phila., Third series, $\mathbf{v}, 1881$. Obituary Notice [Dr. Isaac Hays], by

S. D. Gross, M.D. Am. Jour. Med. Sci., July, 1879, p. 281. 
of the Building Fund that, on the retirement of Dr. Hays in 1869, he was almost as a matter of course elected President. His withdrawal on age from active service in the United States Navy had provided him with leisure for congenial employment, and his connection with the Academy, the American Philosophical Society and the College of Physicians, was productive of the most beneficial results.

After a quiescence of seven years, the Biological Department had been revived, in 1868, by union with the Microscopical Society, under the title Biological and Microscopical Section. Dr. R. S. Kenderdine was President of the Microscopical Society and Dr. Leidy of the Biological Department. When the union was effected Dr. William Pepper was elected Director. He characteristically imparted vitality to the proceedings of the first year, in which J. Gibbons Hunt, Dr. Leidy, Dr. J. H. McQuillen, Dr. Horatio C. Wood, Jr., Dr. S. Weir Mitchell and W. H. Walmsley took an active part. Fragmentary proceedings were published during the three succeeding years as supplements to the Academy's volume, and were then suspended. The meetings of the Section, however, have been continued, and occasional receptions have been held. The semi-centennial of the formation of the Section was celebrated last year by an enjoyable banquet, at which speeches were made reminiscent of old times and in affectionate commemoration of those who had labored and gone before.

Through the efforts of Mr. Tryon, a Conchological Section had been established in 1866. Its administration resulted in the completion of the arrangement of the conchological collection which, because of the zeal of Tryon and his successor, Dr. Pilsbry, is probably the equal of any to be found elsewhere.

The removal to Nineteenth and Race Streets was begun on the 2d of September, 18\%5, Messrs. George W. Tryon, Jr., and Charles F. Parker having been engaged on salary to transfer the collections to the new building. The transfer of the library was made early in 1876 , the librarian making special acknowledgment for assistance to James A. Ogden and John A. Ryder, both at the time Jessup Fund students.

The building had been completed at a cost of $\$ 193,682.29$. The sum of $\$ 50,000$ had been subscribed from the amount realized by the sale of the old building, this sacrifice being made to secure the arrangement of the library and museum in time for the visitors 


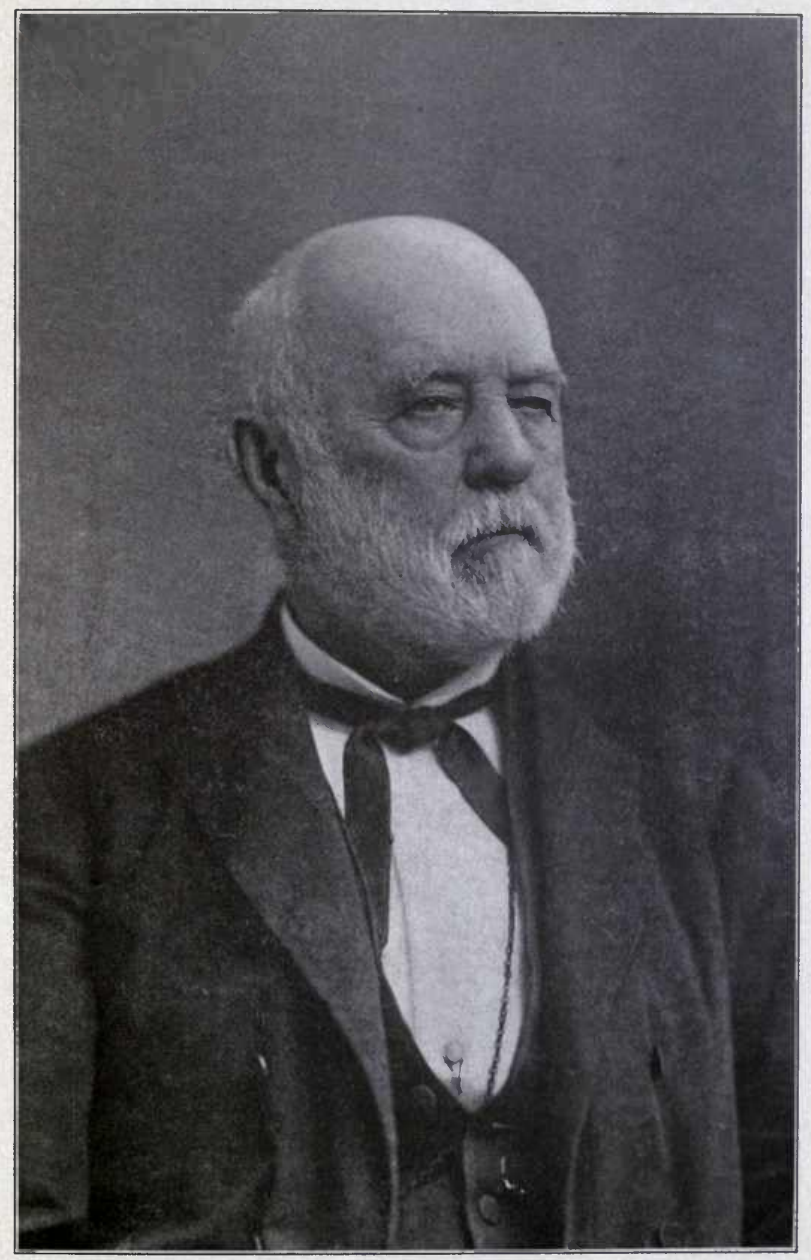

W. S. W RUSCHENBERGER, 1807-1895. 

attending the Centennial Exposition, from whom large additions to the revenues were expected in fees of entrance to the museum. Interest was, however, so concentrated on the exhibition in Fairmount Park that sightseers had little time for anything else, the additional income was only partially realized, the expenses of administration were greatly increased, and for the next few years the Treasurer annually reported a deficit.

Mr. Tryon, not entirely satisfied with the condition of affairs, resigned his position as Curator in July, 1876. His actiou was probably for the benefit of science as he thereafter was able to devote his time to his conchological studies without interference from outside engagements.

In November, 1875, it had been agreed that the American Entomological Society should be received into the Academy, and on May 16th of the following year the Entomological Section was organized on the basis of the proposed union, the Society retaining its corporate existence as far as the administration of its trust funds made it necessary. The union has been to the advantage of both institutions. The entomological interests of the Academy, almost entirely neglected from the removal of Say to the West until 18\%6, have been most judiciously administered, especially since the appointment of Dr. Henry Skinner as Conservator in December, 1884.

The organization of the Botanical Section was reported the following month. It was mainly due to the efforts of Mr. Thomas Meehan, who had succeded Dr. John L. Le Conte as one of the Vice-Presidents in 187\%, retaining the office until his death in 1901. He devoted much time to the increase and arrangement of the herbarium in association with $\mathrm{Mr}$. John $\mathrm{H}$. Redfield, the Conservator, whose later years were devoted to botanical studies, although prior to $\mathbf{1 8 7 6}$ he had done good work in conchology. Mr. Meehan was a prudent councillor, active in his support of all enterprises for the public good. His personality was such as to inspire confidence, and this quality was productive of great benefit to the Academy when, in 1879, his friend, Henry N. Johnson, ${ }^{20}$ influenced solely by his esteem for Mr. Meehan, left his entire estate, on the death of his wife, to the society. Mrs. Johnson died in 1885, and the resulting increase in the Academy's resources

20 Biographical Notice of Henry N. Johnson. Proc. A. N. S. P., 1885, p. 381 . 
went far to relieving necessities which were yearly becoming more pressing. The estimated value of the Johnson estate was $\$ 52,083$.

Modification of the By-Laws adopted in $18 \% 6$ provided for the appointment of Professors and Assistant Professors, who were to be intrusted with the arrangement, increase and preservation of the collections. Under these provisions a number of professors were appointed by the Council. The lecture fees were not enough to defray expenses, proving, it was believed, that the attempt to establish systematic teaching could not be successfully realized in the absence of endowments, and the By-Laws defining the professorships were subsequently repealed.

'After the resignation of Mr. Tryon, the arrangement of the collections was continued by Mr. Charles F. Parker, ${ }^{21}$ who had earlier given devoted service to the care of the herbarium and had been elected Curator in 1873. Mr. Parker succeeded Mr. Tryon as the salaried Curator-in-Charge. He served most efficiently until 1883, when his death was, it is believed, hastened, if not caused, by the tireless discharge of his duties.

Frequent acknowledgment is given by the Curators at this time to John A. Ryder ${ }^{22}$ for assistance in the care and arrangement of the collections. He had been appointed a Jessup Fund student, after a first unsuccessful application, in 18\%4, being indebted mainly to Mr. Meehan for his selection. His work as an attaché of the United States National Museum and of the United States Fish Commission, and subsequently as Professor of Comparative Histology and Embryology in the University of Pennsylvania, together with the high value of his contributions to the literature of philosophical biology, entitle him to be considered the most distinguished of those who have been assisted by the Jessup endowment. He died at the height of his scientific vigor, full of ambitious designs for the future, in 1896.

Dr. Henry C. Chapman succeeded Mr. Tryon as Curator in August, 1876, but served only until the end of 187\%. He had been elected a member in 1868, and immediately availed himself of the resources of the library and museum for the enthusiastic

21 Obituary Notice of Charles F. Parker, by Isaac C. Martindale. Proc. A. N. S. Phila., 1883, pp. 260-265.

22 A Biographical Sketch of John Adams Ryder, by Dr. Harrison Allen. Proc. A. N. S. Phila., 1896, pp. 222-256. 
prosecution of his studies in comparative anatomy. He was induced to resume the duties of the Curatorship in June, 1891, succeeding his dear friend, Dr. Leidy. He held the position until 1904, when he declined a re-election, and was succeeded by William $\mathrm{S}$. Vaux, Jr.

The heirs of Joshua T. Jeanes, who died suddenly January 3,1880 , gave to the Academy $\$ 20,000$, the sum which he had indicated his intention of bequeathing in a pencil memorandum on the margin of his will. The interest of Mr. Jeanes in the society was due to the association of his brother, Joseph, with all matters likely to advance its interests since his election to membership in May, 1853. It was through the liberality of Joseph Jeanes, in association with William $P$. Wilstach, that provision was made for the publication of Leidy's fine work, The Extinct Fauna of Dakota and Nebraska, constituting the seventh volume of the quarto Journal. His contributions for the increase of the library were frequent, and, in truth, every department benefited by his desire to advance the cause of science. In June, 1898, his sister, Anna, conveyed to the Academy a gift of $\$ 20,000$, to be known as the Mary Jeanes Museum Fund.

The Mineralogical Section was founded in 1877. In 1879 its scope was broadened and its name changed to the Mineralogical and Geological Section. Reports of its work were, for a time, contributed to the Proceedings. Its meetings are held regularly, and much good is effected by a series of annual field excursions in the Spring and Fall.

A severe loss was sustained in May, 1882, in the death of William S. Vaux, ${ }^{23}$ who had been elected a member in 1834 . He had served the society effectively and generously for more than forty-eight years, during which time, except when absent from the city, he seldom allowed a day to pass without a visit to the Hall in the discharge of his duties as Curator, which position he had held continuously since 1838 . He was earnestly interested in all the building enterprises, and gave liberally to them himself, contributing to the last building fund the largest sum given by an individual. He bequeathed to the Academy his collections of minerals and archæological specimens, with the exception of ten of

23 Notice of William S. Vaux, by W. S. W. Ruschenberger. Proc. A. N. 8. Phila., 1882, pp. 111, 112. 
the minerals to be selected by his brother. He also left $\$ 1,000$ to provide additional cases and $\$ 10,000$, of which the income was to be expended for the care and increase of the collections.

The will provided for the appointment of a special Curator and under its terms Mr. Jacob Binder assumed the duty of removing, arranging and increasing the collections, declining the compensation which the Council was empowered to define. He had been elected Curator in 1882, to fill the vacancy caused by the death of Dr. R. S. Kenderdine. To fit himself for his duties as Vaux Curator he attended courses of lectures on mineralogy at the University of Pennsylvania under Dr. Koenig, the result being apparent in the satisfactory arrangement of the collection according to the system of Dana. He served as Curator until 1892, when failing health forced him to decline a re-election. Dr. Joseph T. Rothrock then held the office for one year, and was succeeded by Arthur Erwin Brown, who has since served continuously.

Dr. Ruschenberger declined a renomination for the Presidency in 1882, and Dr. Leidy, having been at last persuaded to become a candidate, his fellow-members evinced their affectionate gratitude by conferring on him the highest office within their gift, an honor which he had repeatedly declined. He still continued to act as Chairman of the Curators, the Library Committee and the Publication Committee, all of which profited by his guidance and advice until his death on April 30, 1891.

Custody of the collections of the State Geological Survey was confided to the Academy by Act of the Legislature in 1883.

On his retirement from the Presidency, Dr. Ruschenberger was elected one of the four Curators, thus becoming, of course, an ex-officio member of the Council, where he continued his services during the rest of his life. His well-earned leisure after his retirement from active duty in the navy was occupied in constant supervision of the building operations, in the revision of his Notices, in the preparation of annual reports during his term of service as President, and in convincing support of the Academy's claims to consideration by means of frequent newspaper articles. He died March 24, 1895.24

24 A Biographical Notice of W..S. W. Ruschenberger, by Edward J. Nolan, M.D. Proceedings Academy Natural Sciences of Philadelphia, 1895, pp. 452-462. 


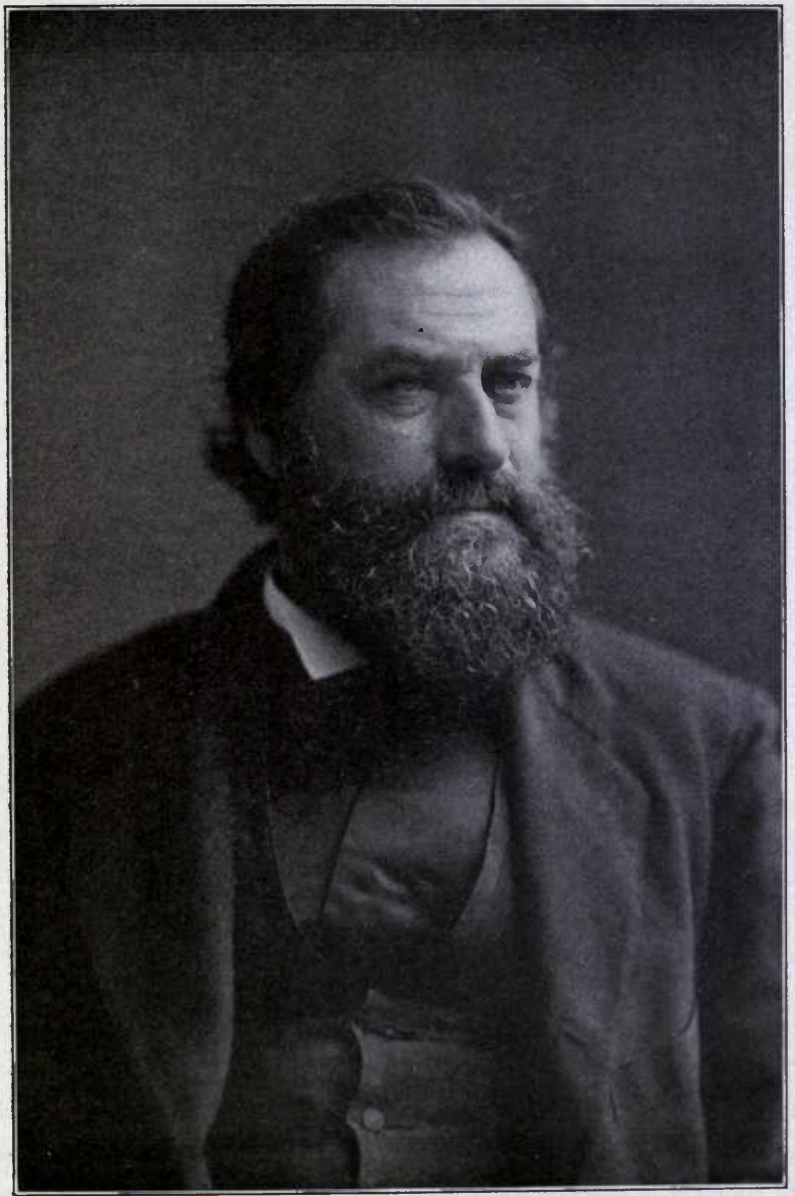

JOSEPH LEIDY, 1823-1891. 
Professor Angelo Heilprin ${ }^{25}$ succeeded Charles F. Parker as Curator in October, 1883, and was immediately appointed Curator-in-Charge. He had begun his studies in the Academy in 1879, on his return from Europe, where he had received a solid scientific training under Huxley in the Royal College of Mines, London, and subsequently in Geneva, Florence and Vienna. While serving as a Jessup Fund student he was engaged in the arrangement of the collection of fossil invertebrata. He suggested as Curator a number of enterprises in which he took more interest than in the routine duties of his executive office. He began the formation of collections illustrating the natural history of Pennsylvania and New Jersey, advocated the opening of the museum on Sundays, organized popular courses of lectures, gave effective assistance in securing appropriations from the Legislature in 1889 and 1891, inaugurated a series of evening receptions and conducted expeditions to Florida, Bermuda, Yucatan and Mexico. He was also the leader of the auxiliary party which accompanied the North Greenland expedition sent out under Lieutenant Peary in 1891, and he commanded the Peary Relief Expedition of the following year.

The meeting of the American Association for the Advancement of Science, held in Philadelphia in 1884, may be regarded as a notable event in the history of the Academy, under whose auspices it was held. It was probably the most important meeting of the kind held in America up to that time.

In their report for 1884 , the Curators make special mention of the Rev. Henry C. McCook's gift of specimens of insect and araneid architecture, with justice regarded as a collection of unique value. Dr. McCook had been elected Vice-President in 1882 to succeed Mr. Vaux. He served until 1900, taking a special interest in the Department of Instruction, the initial activity of which was almost entirely due to his enterprise and zeal. His collections, illustrating the anatomy and natural history of ants and spiders, were made during the prosecution of his studies in the brief intervals of exacting professional duties.

The Academy, in 1888, accepted from Mrs. Emma W. Hayden an endowment of a memorial to her husband, Dr. Ferdinand V. Hayden. Provision was first made to confer a bronze medal and the balance of interest on the fund as a recognition of the best

25 Memorial Notices. Bulletin of the Geographical Society of Philadelphia, vol. vi, No. 1, Jan., 1908, pp. 1-30. 
publication, exploration, discovery or research in the sciences of geology and paleontology. The bronze medal was awarded annually until 1899, when the deed of trust was modified so as to provide for the conferring of a gold medal once every three years. ${ }^{26}$

An appropriation of $\$ 50,000$ for building purposes was received from the Legislature in 1889, and plans for the extension of the building, involving an outlay of $\$ 239,000$, were considered. A second appropriation for a like amount was secured in 1891.

An invitation from the University of Pennsylvania to remove the buildings to a plot of ground in West Philadelphia, immediately adjoining those of the University, was received in 1889, and after mature consideration was declined by a vote of 68 to 3 . A second proposition, with a like intent, was quite as decidedly rejected the following year.

The formation of an Ornithological Section was authorized in May, 1891.

The last meeting presided over by Dr. Leidy was that of March 10, 1891. His death, on April 30, inflicted on the Academy the greatest loss it had ever sustained. He had served the society most devotedly for forty-six years in almost every position within its gift. The range of his scientific accomplishments was indicated at the memorial meeting held May 12th, when his work in vertebrate anatomy was considered by Dr. Harrison Allen, in invertebrate anatomy by Dr. Henry C. Chapman, in paleontology and geology by Professor Angelo Heilprin, in mineralogy by Joseph Willcox, and in botany by Dr. James Darrach. An appreciative biographical notice $^{27}$ was prepared by Dr. Chapman in which his claims to permanent recognition as one of the greatest naturalists of America, and indeed of the world, were ably sustained. A bibliography attached to the memoir credits him with 553 papers dealing with topics in almost every department of natural history. A bronze statue in commemoration of his standing in the scientific world

26 The recipients of the award have been as follows: 1890, James Hall; 1891, Edward D. Cope; 1892, Edward Suess; 1893, Thomas Henry Huxley; 1894, Gabriel Auguste Daubrée; 1895, Karl A. von Zittel; 1896, Giovanni Capellini; 1897, A. Karpinski; 1898, Otto Torell; 1899, Gilles Joseph Gustave Dewalque; 1902, Archibald Geikie; 1905, Charles Doolittle Walcott; 1908, John Mason Clarke.

27 Memoir of Joseph Leidy, M.D., LL.D., by Henry C. Chapman, M.D. Proc. Acad. Nat. Sci. Philad., 1891, pp. 342-388. 


\section{The Academy of Natural Sciences}

adorns the pavement of the City Hall. It is to be hoped that it will, in the near future, be moved to Logan Square, in immediate proximity to the institution which he loved so well and served so loyally, and within the walls of which he accomplished much the greater part of his work.

Charles E. Smith ${ }^{28}$ succeeded Aubrey H. Smith as a member of the Council. He was immediately appointed on the Publication Committee. In this position he rendered most important service as a judicious adviser and an extraordinarily accurate proofreader, until his death, April 15, 1900, in his eightieth year. His interest in the Academy was shown by the bequest of his botanical collections, books, maps and letters, and one-sixth part of the sum realized from the sale of his real and personal property. The latter amounted to about $\$ 75,000$. Philip P. Calvert was placed on the Publication Committee to fill the vacancy caused by the death of Mr. Smith.

The Rev. Dr. McCook having resigned his position as one of the Vice-Presidents, a minute of appreciation of the high value of his services to science was placed on the records. He was succeeded by Arthur Erwin Brown, Sc. D.

Out of respect to the memory of Dr. Leidy, the office of President was allowed to remain vacant until the annual election in December, 1891, when General Isaac Jones Wistar was elected his successor. In the meantime the By-Laws had been amended so as to provide that no member should be eligible to the office of President for more than four consecutive terms.

General Wistar was a prudent adviser and conducted the affairs of the society with dignity and efficiency for the next four years. In 1892, he contributed to the Proceedings an able paper on the quantity, rate of consumption and probable duration of North American coal and the consequence to air breathing animals of its entire consumption. He died September 18, 1905. ${ }^{29}$

The new lecture hall was transferred by the Board of Trustees of the Building Fund in February, 1892, the opening address being delivered on the 22d of that month by the Rev. Dr. McCook.

An expedition for the exploration of West Greenland under the command of Lieut. R. E. Peary had been fitted out by the Academy

28 Memoir of Charles E. Smith, by E. A. Scott. Buffalo, 1902.

29 Nat. Encycl. of Am. Biogr., xii, 359. 
in 1891, a party of associates more directly representing the society, consisting of Messrs. Sharp, Holt, Hughes, Burk, Keely and Mengel, being under the leadership of Professor Heilprin. Considerable material new to science and to the museum was obtained. Because, perhaps, of incomplete instructions, serious misunderstandings arose among the members of the party on their return which, however, did not prevent the sending of an expedition under the command of Professor Heilprin to the relief of Peary the following year. This party consisted of Henry G. Bryant, second in command; Dr. Jackson M. Mills, William E. Meehan, Samuel G. Entrekin, Frank Stokes, Albert W. Vorse, Charles E. Hite and the leader. The object of the expedition was accomplished successfully. Lieut. Peary and those left with him in Greenland the year before, with the exception of John Verhoeff who was lost, were landed in Philadelphia, September 23d. Extensive collections were brought back and the leader testified in his report that in this party good fellowship at all times prevailed.

An Anthropological Section was formed in 1895 with Harrison Allen as Director. The interest in the organization was at first active, but after the deaths of Doctors Brinton and Allen, it was not sustained and no meeting having been held or report presented for the preceding twelve months, the section ceased to exist at the end of 1898.

Nearly one-half of the accessions to the library in 1895 had formerly belonged to Dr. James Aitken Meigs. ${ }^{30}$ He had served as Librarian from August, 1856 to May, 1859. He died March 9, 1879 , and his father retained possession of his books and instruments until his death, when he bequeathed them to the Academy with the sum of $\$ 20,000$, one-half for the increase of the library and the rest without restriction or condition.

Dr. Robert H. Lamborn, ${ }^{31}$ who died in 1895 , bequeathed his estate to the Academy "to be used in biological and anthropological researches, the income only to be used and the principal invested." Question as to the validity of the will under the New York State law having been raised by the heirs-at-law, a compromise was effected on the basis of one-half coming to the society and the balance to

30 Memoir of James Aitkin Meigs, by Henry C. Chapman, M.D., Trans. College of Phys. Phila., Third series, v, pp. 117-133.

31 Biographical Notice of Robert Henry Lamborn, by Carrie S. Aaron. Proc. A. N. S. Phila, 1901, pp. 486-490. 
them. A conservative estimate places the value of the Academy's portion of the estate at half a million. It now became possible to broaden the work of the institution in various ways.

Among the sources of increase of the museum reported by the Curators year after year is the continued interest of the Rev. Dr. L. T. Chamberlain, who, out of regard for the memory of his father-in-law, Dr. Isaac Lea, has furnished cases for the arrangement of the collection of fossils associated with his name. He has provided for its increase by fitting out expeditions to the Eocene and Oligocene deposits of the South.

Having completed his fourth year as President of the Academy, General Wistar was succeeded by Dr. Samuel Gibson Dixon, who had been elected a member in 1890. Shortly after his election he had resigned his professorship of Hygiene in the Medical Department of the University of Pennsylvania and transferred his laboratory to the Academy, where he continued his bacteriological researches and perfected the biological product with which he had produced immunity to tuberculosis in the lower animals. ${ }^{32}$ He had been elected one of the four Curators at the annual meeting in 1891, and immediately instituted a number of reforms in the administration of the office. He was appointed Professor of Bacteriology and Microscopic Technology, October 24, 1892 , and held the position until 1896, when he was compelled to relinquish it because of the pressure of other engagements.

The year 1896 was made memorable by the opening of the central section of the building and the consequent improvement in the arrangement of the collections.

Notable action was taken in May, 1899, when a revision of the By-Laws was adopted providing for important changes of administration. Assistant Curatorships were substituted for the Professorships, the clause limiting the possible continuous term of the Presidency to four years was repealed, and provision was made for the appointment of a Committee on Accounts in addition to the Committee on Finance.

The alteration of the By-Laws enabled the Academy to continue Dr. Dixon in the Presidency on the termination of his fourth year of service, and he has since been re-elected annually to the office. He has also served continuously as Executive Curator.

32 Medical News, October 17, 1889. 
During the administration of Dr. Ruschenberger it had been his practice to read at the annual meeting a résumé of the history of the year. These had been discontinued until 1901 when, at the beginning of the new century, Dr. Dixon prepared a summarized account of the operations of the society during the intervening twenty years.

Because of the constantly increasing tendency to the division of scientific interests into specialties, the organization of sections and special societies, and the consequent interference with attendance on general meetings, an amendment to the By-Laws was adopted in 1903, providing for the holding of meetings on the first and third Tuesdays of each month from October to May, inclusive, thus reducing the number of sessions from fifty-two to sixteen.

An appropriation of $\$ 20,000$ from the State Legislature, in 1905, was expended in replacing the roof of the old building by one which more effectually safeguarded the collections from damage by storms. Another appropriation of $\$ 150,000$ received last year has secured the erection of a fire-proof building on the remaining section of the lot. In the rear portion of the structure the library has been arranged in five tiers of steel stacks, while the front is divided into a lecture hall, and a reading room in connection with the library.

The four Departments of the Academy through which its work is accomplished are the Library, the Museum, the Publication Office and the Department of Instruction and Lectures.

\section{THE LIBRARY}

- The formation of a library was one of the first subjects to engage attention. At the initial meeting a committee, consisting of Dr. Troost and Mr. Shinn, was appointed to consider "which are the fittest periodical works to engage at first instance for the accommodation of the society."

No report seems to have been received from this, the first Library Committee, but under date of March 17, 1812, a memorandum records that "Mr. Shinn will accommodate the society with the Mineralogical Journal of Dr. Bruce; Mr. Parmentier, the Aurora and a map of Switzerland; Dr. Mann, the Monthly Magazine for 180\%. Dr. Troost and Mr. Parmentier have engaged for 
the use of the society the Annales de Chymie and the Annales des Arts et de Commerce. Mr. Shinn is commissioned to procure for account of the society the Archives of Useful Knowledge of Dr. Mease and the Medical Museum of Drs. Mitchell and Miller. Agreed to procure the Repertory of Arts from London." Davy's London Institution Lectures, Nicholson's Journal, Murray's, Thompson's and Davy's Chemistrys and Tilloch's Magazine were suggested as desirable. It is interesting to see how largely the first members were concerned with physics and chemistry, subjects which for years have received little or no attention in the Academy.

The growth of the library was slow until 1816 when the newly elected President, William Maclure, began his donations which, in 1819 , had reached nearly 1,500 volumes. A portion of his library was transferred from New Harmony in 1834.

A catalogue of the library was published in the Journal for 1817 to 1824 when there seems to have been in the possession of the society 1,675 volumes embracing 672 titles. Another catalogue published in 1836 gives the number of volumes at 6,890 of which 5,232 are credited to Mr. Maclure. In 1841 the collection had increased to 7,000 . In May, 1845 , Dr. Thomas B. Wilson presented Owen's History of British Fossil Mammalia and Birds and from that date until his death in 1865 , more than ten thousand volumes were given by him. His brother, Edward Wilson, presented 4,184 rare volumes and pamphlets of the last century, and a valuable selection from Dr. Wilson's library was received after his death from another brother, Rathmel Wilson. Dr. Wilson bequeathed to the Academy $\$ 10,000$, the interest to be used for the continuance of his subscriptions and as a contribution toward the salary of the Librarian. A small amount had been received from the sale to the Historical Society of Pennsylvania of a collection of historical documents given by Mr. Maclure, and a little was secured from time to time by subscription or from the sale of duplicates, etc., but no permanent endowment was available until 1875 when Isaiah V. Williamson gave $\$ 25,000$ in ground rents, the interest to be expended for the purchase of books.

The John Warner Library of about 1,045 volumes and 1,200 pamphlets, mostly on mathematics, was received in 1892 and the library of Dr. James Aitken Meigs consisting of 5,089 volumes was bequeathed to the Academy by his father, together with $\$ 20,000$, in 1895. 
The old hand lists were replaced in 1885 by a regulation card catalogue which has been kept up to date. An Assistant Librarian was appointed in 1890. The library, exclusively for reference, now contains about 60,000 volumes, almost entirely on the natural sciences. In many respects it is the most important collection of the kind in America. It is especially distinguished for its complete sets of early Journals and Transactions and for finely illustrated monographs in all departments of zoölogy and botany. Its sources of growth are the incomes of the Wilson, the I. V. Williamson and the Meigs Funds, supplemented within recent years by liberal appropriations from the treasury. These sums provide the proprietary journals and works on general science, while the publications of learned societies, perhaps the most important part of the library, are secured by exchange of the Proceedings and Journal.

The arrangement of the library has been considered a model of convenience by all having occasion to consult the books. They have been removed to the new building where they are placed in a fireproof compartment fitted up with tiers of steel stacks. Muchneeded increase of room has thus been secured.

\section{THE MUSEUM}

Mr. Witmer Stone, one of the Curators, states that the Academy's museum to-day, both for its historic value and the extent of its collections, is one of the most important in existence. As in the case of all the older scientific institutions its arrangement has undergone material changes in the course of time. The old idea of having all specimens displayed in show cases has been superseded by the establishment of two distinct collections: an exhibition series selected and arranged primarily for the education of the public and a study series compactly arranged in the laboratories and study rooms, where the large suites of specimens required in the work of modern specialists may be accumulated and preserved. Perishable material which has but a comparatively short life in exhibition cases is here preserved from the ravages of light, dust and insects. One of the features of the museum is the large number of type specimens which served as the basis of the work of the eminent naturalists who have figured in the history of the Academy, access to which is indispensable to the students of the present day.

An idea of the extent of the collections may be gained from recent examinations of the catalogues. The vertebrate animals 


\section{The Academy of Natural Sciences}

number about 130,000 specimens, 12,000 being mammals, 60,000 birds, 20,000 reptiles and 40,000 fishes. The insects are estimated at nearly 400,000 specimens and the shells at a million and one-half. There are in the cases 50,000 specimens of fossils, 30,000 minerals, 20,000 pieces of archæological material and over 600,000 preparations of dried plants. Nearly all the departments are now in the care of specialists and the collections are growing at a rapid rate, many of the study collections being equal or superior to those of any other institution in America.

\section{PUBLICATIONS}

No one act of the society contributed so much to its prosperity as the publication of the Journal, commenced in 1817 and continued at irregular intervals for a period of twenty-five years. The series consists of eight octavo volumes, illustrated by lithographic and engraved plates, and contains contributions from nearly all the active naturalists of the period, who had, indeed, scarcely any other avenue of publicity for the details of their original investigations. The second series of the Journal, in quarto, was begun in December, 184\%, and is still continued. Thirteen volumes have been completed. It contains papers requiring more elaborate illustration than can be supplied in the octavo form, and the plates throughout the series are of a high artistic excellence. The numbers, as issued, are exchanged with societies which publish Journals or Transactions of equal dignity.

The publication of the Proceedings was commenced in March, 1841, the sixtieth volume being now completed. Like the earlier Journal, it supplied a need which was then more urgent, as the workers were more numerous than formerly, of a vehicle of communication with the scientific world. Continuous memoirs and the proceedings of the meetings, including verbal communications and comments made on them, form the contents. Volumes iii to vii, inclusive, of the American Journal of Conchology, were published by the Conchological Section, under the editorship of Geo. W. Tryon, Jr., who had prepared volumes $i$ and ii as a private enterprise. The Manual of Conchology, also begun by Mr. Tryon, was bequeathed by him to the Conchological Section of the Academy, and was published under the direction of Dr. Henry A. Pilsbry until 1904, when, on the dissolution of the Section, it was continued by Dr. Pilsbry as one of the Academy's publications. Since the 
death of Mr. Tryon seven volumes of the first series and fifteen of the second have been issued, every species of which a figure can be obtained being illustrated by colored lithographic plates.

Since the formation of the Entomological Section by the union of the American Entomological Society with the Academy in 1875, the publication of the Transactions of the Society has been continued. The Entomological News, embracing the proceedings of the Entomological Section was begun in 1890, and the nineteenth volume has been completed.

The several series of the publications form 151 volumes. The output for the year 1908 amounted to 1,936 pages and 133 plates. It is gratifying to know that the quantity of the matter published is in no sense at the expense of its quality. The importance of the Academy is measurably dependent on the discoveries announced in its publications. They are the organs of speech of the society by means of which it holds communication with naturalists in all civilized countries. They encourage the student to labor, for investigation would be purposeless if the results could not be given to the world.

\section{LECTURES AND INSTRUCTION}

On the acquisition of the Seybert collection of minerals in August, 1814, Dr. Gerard Troost, the President, delivered a course of lectures on mineralogy. Courses on entomology were delivered by Mr. Say and on botany by Drs. Waterhouse and Barnes. The latter were so successful that they were repeated the following year. Soon after the Academy's occupancy of the hall in Gilliams' Court, Mr. Shinn gave discourses on chemistry, and this form of activity was kept up until the removal to the building at Twelfth and George's Streets, twenty-five lectures having been delivered in 1824 by Messrs. Coates, Darrach, Gilpin, Godman, Griffith, Harlan, Hays, Keating, Lea, Mitchell, Patterson, Say and Troost. No lectures seem to have been delivered in the building at Twelfth and George's Streets, probably because of lack of accommodation, but a fine lecture room was provided in the new hall on Broad Street, and provision was made in 1840 for renting the room to lecturers on science, literature and the liberal arts, on such terms as might be thought proper by the Lecture Committee. The use of the room for such purposes was not found to be of practical importance, and it was subsequently appropriated for the arrangement of a portion of the collection until the completion of another 
story to the building in 1855 , when part of the library was moved into it, and the weekly meetings were held there until the removal to South Logan Square.

In $18 \% 6$, By-Laws were adopted providing for the appointment of thirteen professors, each with authority to appoint one or more assistants. 'A number of these positions were filled and acceptable courses of lectures were delivered by J. Gibbons Hunt on histology and microscopic technology; by Henry Carvill Lewis, on mineralogy; by Angelo Heilprin, on invertebrate paleontology and geology; by Benjamin Sharp, on lower invertebrata, and by Daniel G. Brinton, on ethnology and archæology. These courses were well attended, and were, under the energetic management of the Rev. Dr. McCook as chairman of the Committee on Instruction and Lectures, productive of excellent results, but none of them secured sufficient return for the adequate compensation of the professors, and, in the absence of endowments, the By-Laws defining the positions were subsequently repealed.

Courses of popular evening lectures were delivered successfully during the winters of 1887 to 1895 . In 1896 a proposition was made by the Ludwick Institute that the Committee on Instruction should coöperate with the Institute in arranging a course of lectures on natural science and allied subjects, to be given in the Academy's lecture hall and to be free to the public though primarily for the benefit of public school teachers, the Ludwick Institute bearing all expenses. Under this arrangement six to eight courses have been given annually by members of the society, the courses for the session of 1908-1909 being as follows: Seneca Egbert, A.M., M.D., "The Prevention of Disease and the Preservation of Health;" J. Percy Moore, Ph.D., "Illustrations of the Life Histories and Habits of the Lower Animals;" Spencer Trotter, M.D., "Anthropology and Ethnology;" Henry A. Pilsbry, Sc.D., "Shell Fish (Mollusks);" Witmer Stone, A.M., "Studies in Local Bird Life;" T. M. Lightfoot, M.S., Ph.D., "Economic Geology;" Stewardson Brown, "Wild Flowers and Seasons;" Henry Skinner, M.D., "Geographical Distribution of Insects."

The following officers were elected at the annual meeting to serve during 1909:

President, Samuel G. Dixon, M.D., LL.D.; Vice-Presidents, Arthur Erwin Brown, Sc.D. and Edwin G. Conklin, Ph.D.; Recording Secretary and Librarian, Edward J. Nolan, M.D.; Cor- 
responding Secretary, J. Percy Moore, Ph.D.; Treasurer, George Vaux, Jr.; Curators, Arthur Erwin Brown, Sc.D.; Samuel G. Dixon, M.D., LL.D., Henry A. Pilsbry, Sc.D., Witmer Stone, A.M.; Councillors to serve three years, Charles B. Penrose, M.D., Charles Morris, Henry Tucker, M.D., Spencer Trotter, M.D.; Committee on Accounts, Charles Morris, Samuel N. Rhoads, Dr. C. Newlin Peirce,* John G. Rothermel and Howard Crawley, Ph.D.

The remaining Councillors are as follows:-

Two Years.-Thomas H. Fenton, M.D., John Cadwalader, Edwin S. Dixon, Henry Skinner, M.D.

One Year.-Dr. C. Newlin Peirce,* Philip P. Calvert, Ph.D., Thomas Biddle, M.D., Frederick Prime.

The Academy is approaching its centenary. For nearly one hundred years its progress has been steady and progressive and during all that time its resources have been employed exclusively for the intellectual advancement of mankind in connection with the work of unselfish and devoted men. Its influence has not been local but has been exerted wherever scientific research is cultivated. With greatly increased resources and with improved methods of administration its honorable record will assuredly be maintained as the years go on.

- Since deceased. 



University of California

SOUTHERN REGIONAL LIBRARY FACILITY

305 De Neve Drive - Parking Lot 17 • Box 951388

LOS ANGELES, CALIFORNIA 90095-1388

Return this material to the library from which it was borrowed.

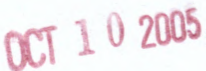




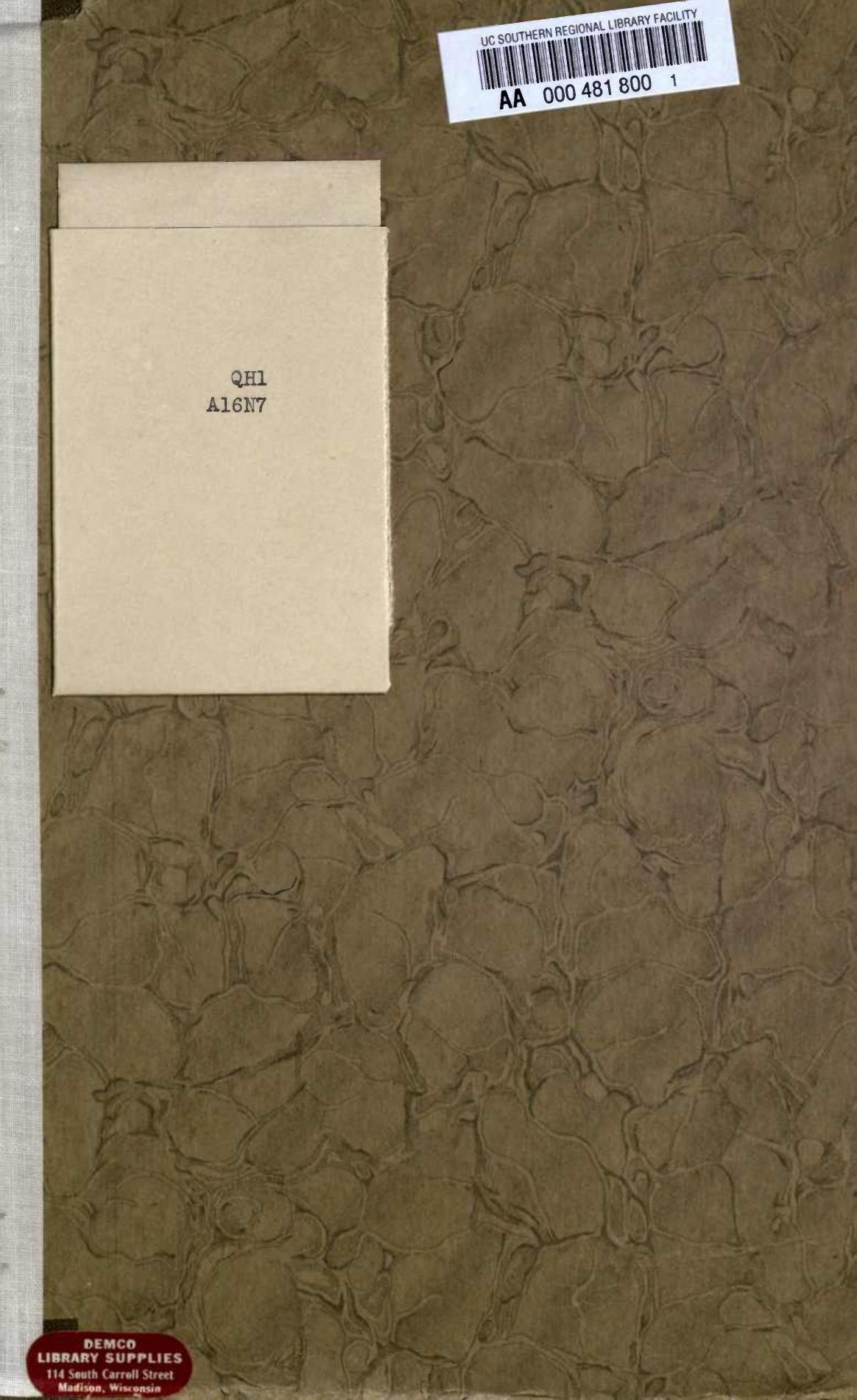


